\title{
DEMOCRACIA RACIAL: empardecer e escurecer para as relações raciais no Brasil
}

\author{
Yuri Miguel Macedo \\ Patrícia Gomes Rufino Andrade
}

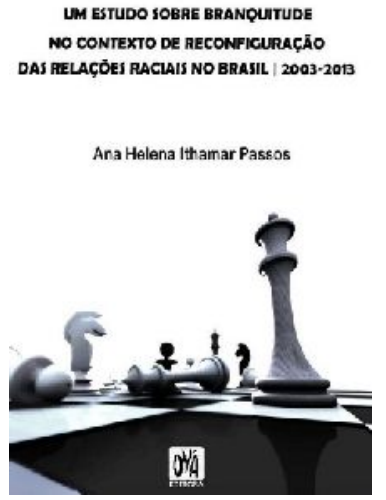

Um estudo sobre branquitude no contexto de reconfiguração das relações raciais no Brasil, 2003-2013. 1.ed. / Ana Helena Ithamar Passos - Porto Seguro: Editora Oyá, 2019, 256 p.

Ao tecer o título desse livro como "Um estudo sobre branquitude no contexto de reconfiguração das relações raciais no Brasil, 2003-2013", Ana Helena Ithamar Passos enquanto professora, pesquisadora, militante, feminista e produtora de conhecimento mostra que o mesmo é fruto das ações políticas e se reconhecem nas mesmas. A autora apresenta como tese principal do seu estudo, que é um dos frutos de seu doutorado, realizado na Pontifícia Universidade Católica do Rio de Janeiro sob a orientação da professora Denise Pini Rosalem da Fonseca e ao imergir na leitura do presente livro que é de uma leveza, agradável, escurecido e empardecido por 6 capítulos que nos ajuda a compreender esse movimento de reconfiguração das relações raciais no Brasil.

$\mathrm{Na}$ introdução a autora traz conceitos e recortes importantes para entender o que é a branquitude, seus conceitos e (pré)conceitos, bem como a explanação sobre a conceituação de racial literacy que "é o conhecimento do saber e da cultura na qual o indivíduo — que é sujeito do seu próprio letramento- está sendo educado. É a condição de um aprendizado a partir de práticas sociais e da pertença sociocultural do sujeito que aprende" (Passos, 2019).

No capítulo "Branquitude: abrindo certas portas" a autora tem intenção de nos aguçar a leitura para responder e trazer as respostas para indagações que carregamos sobre como é visto o branco e negros no Brasil e principalmente nos remete a repensar sobre "Com a emergência dos estudos críticos da branquitude surge o questionamento sobre quem, afinal, é branco brasileiro? É mais: o que se coloca também é o que seria "tornar-se branco"? A priori esta não nos parece uma resposta difícil, posto que a sociedade brasileira, por mais que reverencie a mestiçagem a nível discursivo, através das nossas práticas sociais e políticas explicita nossos valores eurocêntricos e, portanto, de brancos." (Passos, 2019).

Seguindo pelo capítulo "Negritude: a reconquista de si e de uma dignidade autônoma", Passos, a partir de Munanga, nos remete a reflexão a partir da compreensão que "Dito isso, adiantamos que uma reflexão a partir dos estudos críticos da branquitude também despontam como um pensamento crítico das relações coloniais. $O$ fato de os estudos sobre branquitude se formarem como um campo de estudo transnacional e de 


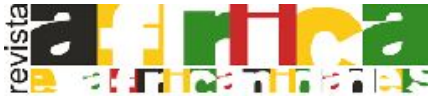 \\ Revista África e Africanidades - Ano XII - n. 31, ago. 2019 - ISSN 1983-2354 \\ www.africaeafricanidades.com.br}

intercâmbio entre ex-colônias e colonizadores corresponde à cadeia de fatos históricos que começa com o projeto moderno de colonização, que desencadeou a escravidão, o tráfico de africanos para o Novo Mundo, a colonização, as formações e construções de novas nações e nacionalidades em toda América e a colonização da África. Portanto, são nestes processos históricos que a branquitude começa a ser construída como um constructo ideológico de poder, em que os brancos tomam sua identidade racial como norma e padrão, e desta forma outros grupos aparecem ora como margem, ora como desviantes e ora como inferiores." (Passos, 2019).

O capitulo "Varrendo a sala para levantar a poeira: o campo, os colaboradores e os eixos temáticos", nos cabe a refletir sobre o processo de busca de dados para escrever sua tese e posteriormente esse livro que está pautado por Passos que: "Por esta razão escolhemos trabalhar com uma população de aproximadamente 30 estudantes de uma Instituição de Ensino Superior particular, localizada na Zona Leste da cidade de São Paulo. Estes colaboradores da pesquisa são entendidos por nós como os sujeitos políticos que compõem o objeto teórico deste estudo: indivíduos pertencentes a um grupo social economicamente em transformação, cujas pertenças raciais fenotípicas, sociais e culturais se localizam fora dos espaços próprios da branquitude, como até agora conceituada. ” (2019)

A partir do capitulo "Parteiros de uma nova nação: os colaboradores e suas falas" o lugar de fala que é apresentado pela autora nos reflete sobre a importância de ter o lugar de fala onde as pesquisas que são resultados de um trabalho em campo, representam por sua vez uma população espoliada, marginalizada e negra. Que precisa ser repensado de quem e para quem é falado, e como é falado. E cabe aqui, ressaltar uma fala da autora: "O fato de ser uma pesquisadora socialmente percebida como branca, e consciente da nossa brancura, facilitou a adesão dos alunos brancos que se mostraram curiosos com o tema da pesquisa. Muitos não conseguiam entender a razão para estarmos interessados em conhecer o que eles - os alunos brancos - teriam a dizer sobre a disciplina. Cabe salientar que alguns sentiram-se tão confortáveis com a nossa brancura, que chegaram a verbalizar, de maneira informal, que gostariam de participar da pesquisa porque estavam incomodados com o professor negro da disciplina, por julgar que ele estaria se posicionando de uma maneira racista com os alunos brancos." (Passos, 2019).

Podemos analisar que este livro em sua totalidade, tem como objetivo central entender o curso da (re)construção das identidades dos sujeitos brancos quando estes se encontram em um processo de (re)conhecimento da sua própria racialidade. O estudo focaliza as relações raciais no Brasil a partir do ano de 2003, com ênfase para as suas configurações políticas frente ao combate ao racismo. O objeto teórico deste estudo é a questão da branquitude brasileira, e suas negociações, frente às novas conjunturas raciais brasileiras. A hipótese que norteia este trabalho é a de que a permanência da ideologia da mestiçagem, enquanto uma estrutura de longa duração (Braudel, 1992), sustenta um discurso de igualdade formal e impede a aquisição de um racial literacy pelos sujeitos brancos em todas as camadas sociais e, em particular, para os indivíduos pertencentes às populações que vivem em espaços de subalternidade social. Desta maneira, assumimos que as representações sociais do branco pobre se assemelham às do negro, dificultando a explicitação da questão racial e suas implicações sociais. A partir de uma metodologia que incorporou o arcabouço teórico do racial literacy como lente de observação, esta pesquisa combinou atividades de observação participante, realizadas durante um semestre letivo em 


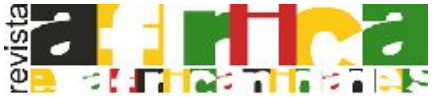 \\ Revista África e Africanidades - Ano XII - n. 31, ago. 2019 - ISSN 1983-2354 \\ www.africaeafricanidades.com.br}

uma classe composta por aproximadamente 30 estudantes da disciplina "História e Cultura Afro-brasileira" oferecida por uma Instituição de Ensino Superior da Zona Leste da cidade de São Paulo, com entrevistas individuais com 11 destes alunos que se autodefiniam brancos ou pardos. Nossas conclusões apontam para o fato de que embora se possam observar importantes processos de transformação em curso, a partir da implementação da Lei Federal 10.639/2003, permanecem as estruturas pelas quais o mito da democracia racial se reproduz, e se atualiza, impedindo que ocorram processos de racialização das identidades que permitam novas relações de poder entre brancos e negros na sociedade brasileira. 